\title{
MEMBANGUN ORGANISASI YANG EFEKTIF MELALUI PERENCANAAN STRATEGIS YANG MEMADAI: KAJIAN PADA UPTD SKB
}

\author{
Agus Sadid*
}

\begin{abstract}
The effectiveness of an organization to empower all its human resources much depends on the capability of the manager to manage the resources to complete both the goals and the objectives of the organization. This article describes how to develop an effective organization of learning center, such as SKB. It also discusses the relationship between strategic planning and an effective $S K B$. This article concludes (1) developing an effective SKB depends on the commitment and consistency, leaderships and the unity of perception, as well as the mission and vision of all managers in SKB; and (2) to obtain the objectives, all capacity of resources should be benefited optimally. Some advantages of having strategic planning for SKB are identified as (1) helping to focus on program, (2) giving guidelines to reach the goal, (3) developing rational frameworks, and (4) evaluating and identifying all possible obstacles.
\end{abstract}

Keywords: developing, an effective organization, planning strategic.

\section{PENDAHULUAN}

Organisasi yang baik tentunya berbeda dengan organisasi yang efektif. Banyak pakar yang berpandangan bahwa organisasi yang baik belum tentu efektif tetapi organisasi yang efektif pastilah merupakan sebuah organisasi yang baik. Misalnya, sebuah organisasi dengan struktur yang lengkap menunjukkan kejelasan hubungan tugas dan tanggung jawab adalah salah satu karakteristik organisasi yang baik. Namun, jika dari struktur yang ada tersebut tidak bekerja dan berfungsi dengan baik maka organisasi tersebut tidaklah disebut sebagai organisasi yang efektif. Sebaliknya, jika dari struktur dan pembagian tugas tersebut berjalan sesuai dengan tugas pokok dan fungsinya serta mampu bersinergi dengan baik maka organisasi tersebut dikatakan sebagai organisasi yang efektif (an effective organization).

Dalam konteks Sanggar Kegiatan Belajar (SKB) maka pandangan di atas mempunyai kesamaan dengan karakteristik organisasi yang efektif secara umum. Memandang sebuah SKB yang efektif harus melihat bagaimana struktur dan pembagian tugas bekerja dengan baik; masing-masing komponen dalam SKB bekerja dan bersinergi untuk menciptakan program-program Pendidikan Nonformal (PNF) yang berkualitas dan memuaskan pelanggan atau klien. Jadi,

* Pamong Belajar SKB Sumbawa Propinsi NTB semua komponen yang terlibat dalam SKB harus terkoordinasi dengan baik. Hal ini sejalan dengan pendapat Hersey dan Blancard (1977) bahwa organisasi yang efektif adalah merupakan sistem kerja sama yang terkoordinasi secara sadar dan dilakukan oleh dua orang atau lebih.

Mencapai keefektifan sebuah organisasi, seperti SKB, memerlukan sebuah perencanaan yang bersifat visioner, yaitu perencanaan yang mampu "membaca" kebutuhan dan mengatasi permasalahan yang muncul. Perencanaan strategis merupakan bagian dari manajemen strategis dalam organisasi. SKB sebagai sebuah Unit Pelaksana Teknis (UPT) yang menangani permasalahan PNF. Dukungan terhadap sebuah perencanaan yang kuat, seperti perencanaan strategis merupakan hal yang mutlak diperlukan, demi mewujudkan sebuah SKB yang efektif.

Namun demikian, tidak semua SKB menyadari arti pentingnya sebuah perencanaan strategis sebagai kerangka membangun SKB yang efektif. Jadi, salah satu kelemahan SKB yang hampir terdapat di semua SKB adalah bahwa SKB belum mempunyai grand planning yang mengover program dan rencana aksi jangka pendek, menengah, dan panjang. Terlebih jika SKB itu sendiri belum memiliki misi dan visi yang kuat serta harus dihayati dan diyakini oleh semua orang yang ada di SKB. Grand planning tersebut akan membawa SKB kepada rel yang jelas, target yang terang, dan 
arah yang pasti. Perwujudan dari grand planning tersebut adalah rencana strategis (strategic planning).

Kekuatan sebuah SKB salah satunya adalah kemampuan SKB dalam merumuskan dan mengimplementasikan sebuah perencanaan strategis. Untuk itu, pembangunan konsepsi tentang sebuah organisasi yang efektif dan memahami peran perencanaan strategis dalam rangka membangun sebuah SKB yang efektif adalah sangat penting. Mengungkap beberapa kelemahan dari SKB salah satunya adalah lemahnya dalam menyusun sebuah perencanaan strategis yang kurang disertai dengan analisis internal dan eksternal, seperti Strength, Weakness, Opportunity, dan Threat (SWOT) sehingga dalam implementasinya kurang touch dengan kebutuhan pelanggan. Kondisi inilah yang membuat SKB semakin jauh dengan konsepsi sebuah SKB yang efektif. Tulisan ini menyajikan pemaparan tentang bagaimana membangun sebuah SKB yang efektif dan peran perencanaan strategis dalam framework keefektifan sebuah organsasi, yaitu SKB yang efektif. Diharapkan dari kajian ini pembaca, terutama anggota organisasi di SKB akan memahami eksistensi perencanaan strategis sebagai sesuatu yang vital yang mampu membangun SKB yang efektif.

Bertolak dari paparan di atas maka permasalahan yang diangkat dan selanjutnya akan dikaji secara komprehensif adalah sebagai berikut.

1. Bagaimanakah membangun sebuah SKB yang efektif?

2. Bagaimanakah peran sebuah perencanaan strategis terhadap pembangunan sebuah SKB yang efektif?

Berdasarkan pada rumusan permasalahan tersebut maka tujuan dari tulisan ini adalah sebagai berikut.

1. Mendeskripsikan bagaimana membangun sebuah SKB yang efektif

2. Mendeskripsikan bagaimana peran sebuah perencanaan strategis terhadap pembangunan sebuah SKB yang efektif

\section{PEMBAHASAN}

\section{Konsepsi SKB yang Efektif (The Nature of An Effective SKB)}

Organisasi merupakan sekumpulan orang yang mempunyai tujuan, misi, dan visi yang sama dan diarahkan untuk mencapai tujuan tertentu. Setiap organisasi akan selalu berupaya untuk mencapai tujuan yang telah ditetapkan. Kemampuan organisasi dalam meraih tujuannya merupakan bentuk keberhasilan organisasi tersebut, dengan kata lain organisasi telah efektif mencapai tujuannya. Tentunya kemampuan organisasi dalam mencapai keefektifannya sangat tergantung pada bagaimana anggota organisasi di dalam organisasi tersebut memanfaatkan sumber dayanya untuk pencapaian tujuan yang telah ditetapkan. Sebagaimana ditegaskan oleh Hoy dan Miskel (1983) bahwa organisasi yang efektif adalah organisasi yang mampu mengoptimalkan sumber daya yang ada.

Dalam konteks organisasi seperti SKB, mengukur keefektifannya dapat dilihat dari: (1) bagaimana SKB memanfaatkan dan mengoptimalkan segala potensi baik Sumber Daya Manusia (SDM) maupun sumber daya yang lain; (2) bagaimana SKB memberikan layanan program-program yang berkualitas kepada pelanggan, yaitu warga belajar dan masyarakat; dan (3) bagaimana SKB menciptakan kepuasan kepada pelanggan dan anggota organisasi dalam SKB. Campbell, Corbally, dan Nystrand (1983) menyebutkan bahwa untuk mengukur apakah sekolah (sanggar) tersebut efektif dan berkualitas atau sebaliknya maka kita bisa mengamati pada hasil atau keluaran yang ada pada sekolah atau sanggar di antaranya: (1) tingkat pencapaian prestasi akademik siswanya, (2) kepuasan kerja, dan (3) perasaan atau pemahaman terhadap konsep keefektifan itu sendiri.

Pandangan terhadap konsep organisasi yang efektif memang sangat beragam, terlebih pada organisasi pendidikan seperti SKB. Salah satunya adalah pandangan dari aspek masukan, proses, dan keluaran. SKB sebagai agen pembelajaran merupakan tempat penempaan manusia menjadi warga belajar yang berkualitas, tidak terlepas dari ketiga komponen tersebut. Pada kelompok belajar PNF, seperti kejar kesetaraan, tidak bisa dipungkiri bahwa keefektifan penyelenggaraan program ini sangat berkaitan dengan bagaimana masukan, proses yang berjalan, dan produk akhir yaitu hasil dari pembelajaran. Dengan demikian, pada konteks ini tidaklah salah bahwa indikator keefektifan sebuah SKB terletak pada masukan (input), proses, dan keluaran (output). Untuk ini, Gibson (1989) menyimpulkan bahwa konsep efektivitas lebih merupakan sebuah siklus antara masukan-proseskeluaran. Masukan yang berkualitas bukan hanya dari aspek pendidikan tetapi juga kemampuan dan kompetensi. Demikian juga proses, bagaimana kegiatan dalam organisasi berjalan, bagaimana fungsi-fungsi 
manajemen diterapkan, dan terakhir adalah komponen keluaran. Pada aspek terakhir keluaran yang mampu meningkatkan image organisasi, tercermin dalam bagaimana prestasi, daya penerimaan masyarakat (societal acceptability), dan performa organisasi yang sempurna (excellent).

Bahkan dalam pandangan Campbell, Corbally, dan Nystrand (1983) tentang konsep sekolah atau sanggar yang efektif, mereka menyebutkan bahwa keefektifan sebuah sekolah atau sanggar terletak pada hal berikut.

1. Proses belajar membelajarkan.

2. Struktur.

3. Individu.

4. Kebudayaan.

5. Politik.

Jadi, dalam pandangan efektivitas mewujudkan organisasi yang efektif merupakan kegiatan yang menuntut sinergitas dan kooperasi yang kuat dari setiap unsur. Untuk mencapai tujuan organisasi atau efektifvitas organisasi maka setiap organisasi dituntut memiliki perencanaan strategis yang memadai. Jadi, efektivitas organisasi pada dasarnya adalah efektivitas individu para anggotanya dalam melaksanakan tugas sesuai dengan kedudukan dan peran mereka masingmasing dalam organisasi tersebut. Untuk menentukan efektif atau tidaknya suatu organisasi merupakan pekerjaan yang kompleks. Individu harus mengetahui karakteristik organisasi tersebut terutama yang menyangkut tugas dan fungsi pokoknya.

Melihat konsepsi sebuah organisasi sekolah yang efektif tentunya berbeda dengan konsepsi sebuah sanggar yang efektif. Konteks sanggar harus dilihat dalam perspektif yang lebih luas. Mengapa demikian? Oleh karena bidang pekerjaan SKB yang lebih kompleks daripada sekolah di pendidikan formal dan menuntut perluasan konsep terhadap pemaknaan sebuah SKB yang efektif. Proses pembelajaran, kurikulum, dan kemampuan Pamong Belajar (PB) dalam melaksanakan program-program PNF dan ketersediaan sarana prasarana adalah beberapa komponen yang terikat secara langsung dalam penentuan keefektifan sebuah SKB.

Dalam pandangan penulis maka penciptaan terhadap sebuah SKB yang efektif sangat tergantung pada hal berikut.

1. Kemampuan kepala SKB dalam mengendalikan organisasi, mengarahkan, serta dan mengkoordinasikan program-program PNF sehingga dapat mencapai tujuan yang telah ditetapkan.

2. Pengelolaan layanan program PNF yang berorientasi pada kepuasan pelanggan, yaitu terpenuhinya kebutuhan belajar warga belajar dan masyarakat akan program PNF di SKB.

3. Mencermati dan menelaah setiap komponen kegiatan meliputi bagaimana masukan, proses, dan keluaran dengan selalu mendasarkan kepada prinsip-prinsip kerja yang profesional.

4. Membangun ruang komunikasi dan kerja sama yang luas kepada anggota organisasi yang terlibat di SKB.

5. Mengoptimalkan sumber daya yang ada, salah satunya adalah SDM SKB yang merupakan aset berharga (valuable asset) sehingga pemberdayaan mereka merupakan kunci dari penciptaan SKB yang efektif.

\section{Upaya Membangun SKB yang Efektif}

Membangun organisasi SKB yang efektif merupakan penerapan dari pemahaman kerja keras, cerdas, dan ikhlas. Pemahaman ini harus melekat kuat pada mindset di setiap tingkat pimpinan, dari manajer puncak (top manager), manajer menengah (middle manager) maupun manajer rendah (lower manager). Setiap unsur pimpinan harus bekerja keras dan mengerahkan segenap kemampuan dan tanpa pamrih, yaitu bekerja mengabdi untuk kepentingan pelanggan melalui pelayanan program PNF yang sesuai dengan kebutuhan belajar pelanggan.

SKB, sebagaimana sebuah sekolah, mempunyai konsep-konsep keefektifan yang kuat. Sebuah sanggar dikatakan efektif jika mampu menunjukkan kinerja yang bagus, baik dari aspek masukan-proses-keluaran. Membangun SKB yang efektif dalam pandangan Edmond (dalam Miskel dan Hoy, 2001) mempunyai pemahaman yang searah dengan membangun sekolah yang efektif, yaitu (1) kepemimpinan yang kuat dari kepala sekolah, khususnya dalam pengajaran; (2) harapan tinggi dari siswa dan guru; (3) penekanan pada kemampuan dasar; (4) suatu lingkungan yang beraturan; dan (5) sistem evaluasi siswa.

Namun demikian, cakupan yang lebih luas diberikan oleh Smith dan Purkey (dalam Miskel dan Hoy, 2001) menyatakan bahwa formula menciptakan sanggar yang efektif adalah:

1. kepemimpinan yang kuat,

2. perencanan kurikulum,

3. tujuan dan harapan yang jelas,

4. waktu tugas,

5. mengakui keberhasilan akademik,

6. iklim yang sehat,

7. peka terhadap masyarakat,

8. pengembangan staf,

9. stabilitas staf,

10. perencanaan kolega dan kolaboratif, 11. manajemen sekolah, 
12. dukungan orang tua dan lingkungan, dan

13. dukungan langsung.

Bertolak dari pandangan di atas maka bahwa upaya membangun sebuah SKB yang efektif bertumpu pada faktor internal dan eksternal. Kepemimpinan kepala SKB yang kuat, keteladanan yang diberikan kepada staf atau bawahan, dan kemampuannya dalam memberikan arahan, bimbingan, dan pembinaan teknis dan nonteknis merupakan unsur yang membangun keefektifan SKB dari dalam. Adapun hal-hal yang terkait dengan lingkungan SKB, iklim organisasi yang sehat, sistem kerja, dukungan sarana atau fasilitas merupakan unsur yang berasal dari luar.

Merujuk pada paparan tentang konsepsi SKB yang efektif di atas maka untuk membangun organisasi yang efektif sangat ditentukan dengan hal berikut.

1. kemampuan dan komitmen anggota kelompok organisasi pada konteks ke-SKB-an. Oleh karena itu, kepala SKB, pamong belajar, dan staf tata usaha merupakan pelaku kunci dalam pembangunan organisasi SKB yang efektif. Kepala SKB sebagai central figure harus memiliki kepemimpinan, kompetensi, dan visi yang kuat agar mampu menciptakan SKB yang efektif.

2. Kepemimpinan yang ditunjukkan oleh para pemimpin SKB baik tingkat top manager, middle manager maupun lower manager. Kepemimpinan yang kuat dari para manager di atas akan memberikan semangat dan inspirasi yang kuat dalam melaksanakan tugas dan fungsi SKB.

3. Kesamaan persepsi, misi, dan visi antaranggota organisasi di SKB. Ketiga hal tersebut sangat penting karena dapat mempertajam pencapaian tujuan dan meningkatkan kinerja SKB.

Terwujudnya SKB yang efektif dapat memberikan manfaat yang besar, manfaat tersebut adalah (1) meningkatkan kinerja organisasi,baik secara kelembagaan maupun individu. Secara kelembagaan yaitu terwujudnya program-program percontohan PNF yang dapat menjadi contoh serta rujukan bagi masyarakat yang ingin menyelenggarakan program sejenis. Secara individu performa atau produktifitas staf (kepala SKB, pamong belajar dan tenaga TU). (2) terbangunnya kondisi atau atmosfir kerja yang kondusif,(good working atmosphere) yaitu kondisi di mana masing-masing staf/pegawai/manajer memahami tugas dan fungsinya dengan baik. Kepala SKB merupakan pemegang otoritas tertinggi dalam proses pengambilan keputusan. Pamong belajar merupakan tenaga fungsional yang melaksanakan semua keputusan atau kebijakan kepala SKB, sebagaimana telah ditetapkan dalam rencana kerja tahunan. Mereka merupakan tenaga profesional dalam pelaksanaan program PNF di SKB. Adapun staf TU adalah tenaga administratif yang melaksanakan urusan ketatausahaan sanggar. Terbangunnya pemahaman yang kuat terhadap tupoksi masing-masing juga akan meningkatkan komitmen dan tanggung jawab staf. (3) meningkatkan daya tawar SKB (bargaining position) kepada stakeholders yaitu kepala diknas kabupaten atau kota, Bupati atau Walikota dan DPRD kabupaten/kota. Semakin tinggi tingkat keefektifan SKB maka semakin baik image SKB dihadapan mereka. Karena bagaimanapun diera Otonomi Daerah (Otda), keberadaan SKB masih banyak yang belum diperhatikan oleh Pemda atau Pemkot. Menunjukan keefektifan SKB salah satunya adalah melalui (a) unjuk prestasi hasil-hasil belajar, (b) gelar kreativitas produkproduk warga belajar binaan SKB.

\section{Konsepsi Perencanaan Strategis (The Nature of $A$ Strategic Planning) bagi SKB}

Pada prinsipnya rencana strategis merupakan serangkaian rencana tindakan dan kegiatan mendasar yang dibuat oleh pimpinan puncak (top manager) untuk diimplementasikan oleh jajaran organisasi dalam rangka mencapai tujuan organisasi. Selanjutnya, dalam Instruksi Presiden (Inpres) No. 7 Tahun 1999 Tentang Pedoman dan Penyusunan Pelaporan Akuntabilitas Kinerja Instansi Pemerintah dalam Sonhadji (2003) menyatakan bahwa konsepsi rencana strategis merupakan suatu proses yang berorientasi pada hasil yang ingin dicapai selama kurun waktu satu sampai lima tahun dengan memperhitungkan potensi, peluang, dan kendala yang ada atau mungkin timbul.

Definisi tentang rencana strategis yang lebih luas disampaikan oleh Sharplin dalam Sonhadji (2003) yang menyatakan bahwa perencanaan strategis merupakan bagian dari pekerjaan manajemen strategis, yaitu merupakan proses formulasi dan implementasi rencana dan kegiatan-kegiatan yang berhubungan dengan halhal vital dapat menembus kebutuhan organisasi (pervasive) dan berkesinambungan bagi suatu organisasi. Kegiatan formulasi sampai dengan implementasi merupakan tindakan dalam perencanaan strategis. Sementara Ivanchevic (1995) menyatakan bahwa perencanaan strategis merupakan keputusan organisasi yang memuat tentang apa yang akan dicapai sesuai misi organisasi dan bagaimana cara yang dilakukan untuk mencapai misi tersebut.

Perencanaan strategis merupakan kegiatan menyusun rencana aksi dan tindakan yang bersifat strategis disertai dengan rumusan visi dan misi, strategi pencapaian tujuan, dan prediksi kemampuan atau kekuatan organisasi dalam mencapai tujuan yang telah 
ditetapkan. Dalam organisasi yang modern, pandangan terhadap rencana strategis menjadi lebih luas tidak hanya rumusan yang mengandung rencana aksi dan tindakan tetapi juga berisi acuan-acuan pengembangan organisasi ke depan. Hal ini jelas bahwa perencanaan strategis merupakan pedoman yang harus ditaati oleh semua anggota organisasi karena keputusan tersebut merupakan keputusan bersama.

Merujuk pada konsepsi di atas maka penulis berkesimpulan bahwa rencana strategis merupakan rumusan kegiatan yang menjadi target atau sasaran organisasi yang hendak dicapai dalam periode waktu tertentu. Sebuah organisasi yang hidup tentunya harus menyertakan rumusan-rumusan kegiatan yang akan dilakukan dan mendesain program yang efektif untuk mencapai tujuan yang telah ditetapkan. Untuk itu, tugas penyusunan rencana strategi adalah tugas berat yang harus direnungkan dan dipahami sebagai sebuah langkah strategis yang menentukan nasib atau masa depan organisasi tersebut. Untuk itu, sebuah rencana strategis yang baik seharusnya: (1) memuat dua formulasi perencanaan, yaitu informasi tentang sekolah dan data kritis; (2) menjaga proses perencanaan; (3) mempertahankan fleksibilitas dalam perencanaan; (4) merancang koordinasi; dan (5) mempertahankan data yang terbaru.

Menempatkan rencana strategis sebagai komponen utama dalam konsep SKB yang efektif adalah sangat penting. Setiap orang yang ada dalam SKB, terutama kepala SKB harus memahami seutuhnya bagaimana proses penyusunan rencana strategis. Ansoff dan McDonnel (1990) menyebutkan bahwa pendekatan dalam penyusunan perencanaan strategis meliputi pendekatan instruksional (instructional program model) dan komprehensif model. Kedua pendekatan tersebut memberikan penekanan yang berbeda dalam hal analisis kebutuhan, asumsi, dan proses. Dalam asumsi misalnya, model instruksional tidak disertakan dalam proses perencanaan strategis sedangkan model komprehensif disertakan karena merupakan bagian yang penting dalam proses tersebut. Pendekatan diterapkan dalam rangka mencapai tujuan organisasi secara efektif dan efisien.

Selanjutnya, mengamati arti pentingnya rencana strategis bagi SKB beberapa makna yang ada dalam rencana strategis adalah sebagai berikut. (1) Sebagai pedoman pelaksanaan dan pengendalian. (2) Menghindari pemborosan sumber daya. (3) Dapat memberikan keuntungan besar bagi organisasi itu sendiri. Hal ini sesuai dengan penegasan Lewis dalam Sonhadji (2003) yang menyebutkan perencanaan strategis sangat penting untuk mewujudkan suatu organisasi yang accountable dan efektif. Argumentasi terhadap pernyataan tersebut adalah sebagai berikut.

1. Diperlukan untuk merencanakan perubahan dalam lingkungan yang semakin kompleks.

2. Diperlukan untuk pengelolaan keberhasilan.

3. Berorientasi pada masa depan, perencanaan strategis memungkinkan organisasi untuk memberikan komitmen pada aktivitas dan kegiatan masa datang.

4. Adaptif dan fleksibilitas merupakan kriteria yang sangat penting dalam perencanaan strategis meskipun pendekatan yang digunakan adalah pendekatan jangka panjang.

5. Meningkatkan efektivitas penggunaan sumbersumber organisasi, baik yang meliputi SDM maupun alam.

6. Meningkatkan produktivitas karena peningkatan efektivitas dan efisiensi dapat meningkatkan produktivitas.

Makna yang lebih luas dari keberadaan rencana strategis bagi SKB adalah sebagai berikut. (1) Memberikan arahan yang jelas tentang apa saja yang harus dilakukan dan bagaimana meraihnya. (2) Memberikan pemahaman yang komprehensif tentang kondisi program-program PNF yang akan, sedang, dan selesai dilaksanakan. Rencana strategis yang memadai, pasti mempunyai prediksi yang kuat terhadap keefektifan dan keberhasilan SKB dalam melaksanakan layanan program PNF. (3) Memberikan pemecahan masalah yang dihadapi oleh warga belajar.

Lewis dalam Sonhadji (2003) kembali menegaskan bahwa beberapa konsep kunci terhadap pentingnya perencanaan adalah sebagai berikut. (1) Perencanan harus mampu bersifat jangka panjang dan pendek. (2) Berkaitan dengan strategi komprehensif dan sistematis. (3) Mengatasi kesenjangan. (4) Mempertahankan variabel internal dan eksternal yang berpengaruh tedarhadap perencanaan. (5) Merupakan proses yang berkesinambungan.

\section{Proses Perumusan dan Implementasi Peren- canaan Strategis di SKB}

Menguraikan tentang proses perumusan dan implementasi perencanaan strategis sangat penting karena justru pada aspek ini banyak kepala SKB yang belum memahami proses kegiatan penyusunan rencana strategis. Pemahaman konsep ini dapat meningkatkan keterampilan kepala SKB dalam menyusun dan merumuskan sebuah perencanaan strategis yang memadai karena merupakan kegiatan penyusunan masa depan. Kegiatan tersebut melibatkan banyak dimensi. Dimensi dalam perencanaan strategis 
meliputi: (1) signifikansi, yaitu tingkat kebermaknaan; (2) fisibilitas, yaitu tingkat kelayakan; (3) relevansi, keterkaitan yang kuat; (4) definitas; (5) adaptabilitas; (6) waktu, merupakan siklus alamiah; (7) pemantauan; dan (8) pokok bahasan (Sa'ud dan Makmun, 2005).

Secara teori perencanaan strategis merupakan kegiatan yang melibatkan banyak pertimbangan dan analisis. Salah satunya adalah analisis Strengths, Weaknesses, Opportunities, dan Threats (SWOT), yaitu merupakan identifikasi beberapa faktor secara sistematis untuk merumuskan strategi perusahaan. Pada konsepsi ini analisis didasarkan pada logika yang dapat memaksimalkan kekuatan (strengths) dan peluang (opportunities) namun secara bersamaan meminimalkan kelemahan (weakness) dan ancaman.
Perencanaan strategis dalam penyusunannya selalu mempertimbangkan juga analisis lingkungan karena pada hakikatnya analisis SWOT adalah analisis lingkungan.

Hal ini diperkuat oleh pernyataan Sharplin (1985) bahwa analisis lingkungan mencakup dua unsur, yaitu (1) analisis eksternal meliputi identifikasi dan evaluasi aspek-aspek sosial, budaya, politis dan teknologi serta kecenderungan yang mungkin berpengaruh, bersifat unpredictabel atau tidak pasti (degree of uncertainty). Analisis eksternal berpusat pada hal-hal yang menjadi kekuatan dan kelemahan; dan (2) analisis internal menyangkut aspek yang berkaitan dengan peluang dan ancaman. Jadi, konsep inilah yang disebut dengan analisis SWOT.

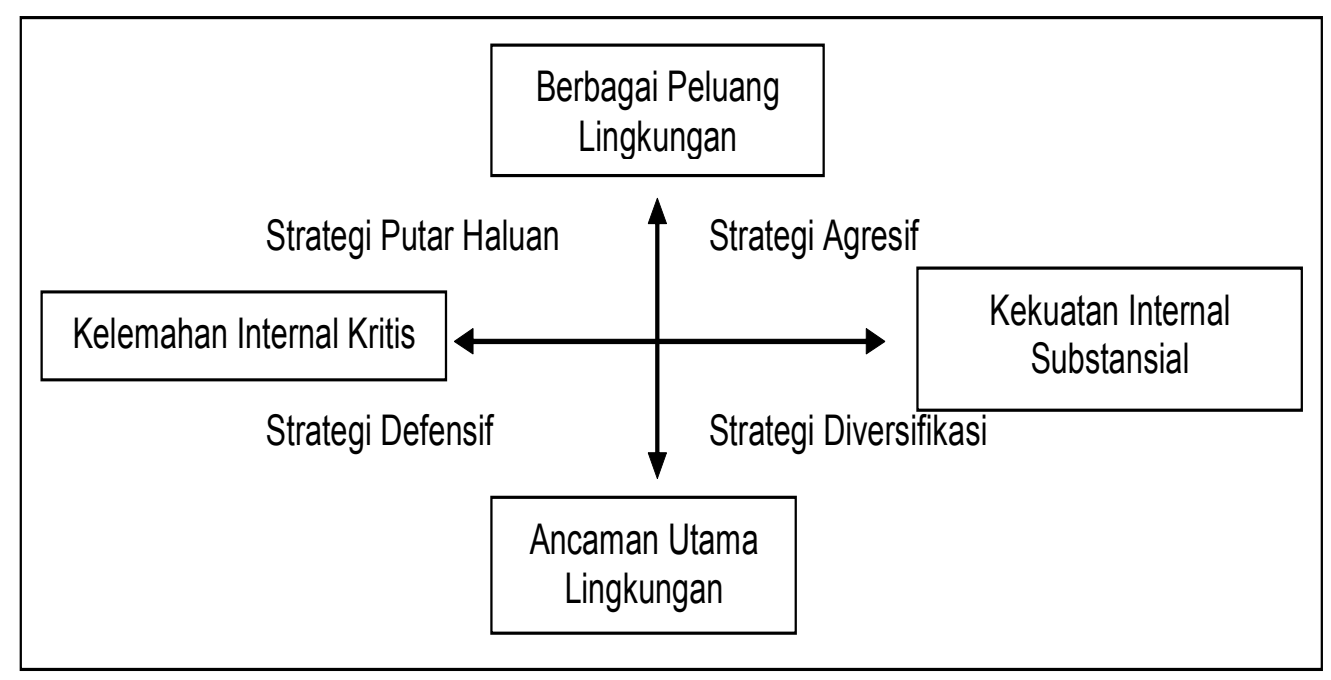

Gambar 1. Diagram analisis SWOT diadaptasi dari Sharplin (1985) dalam Sonhadji (2003)

Proses perencanaan strategis merupakan aktivitas yang melibatkan banyak unsur, untuk itu konsep kerja tim (teamwork) harus benar-benar dipahami. Masing-masing langkah merupakan bagian yang tidak terpisah dari langkah sebelumnya (interdependence). Secara detail, Lewis dalam Sonhadji (2003) menggambarkan proses perencanaan strategis dalam bentuk gambar berikut ini.

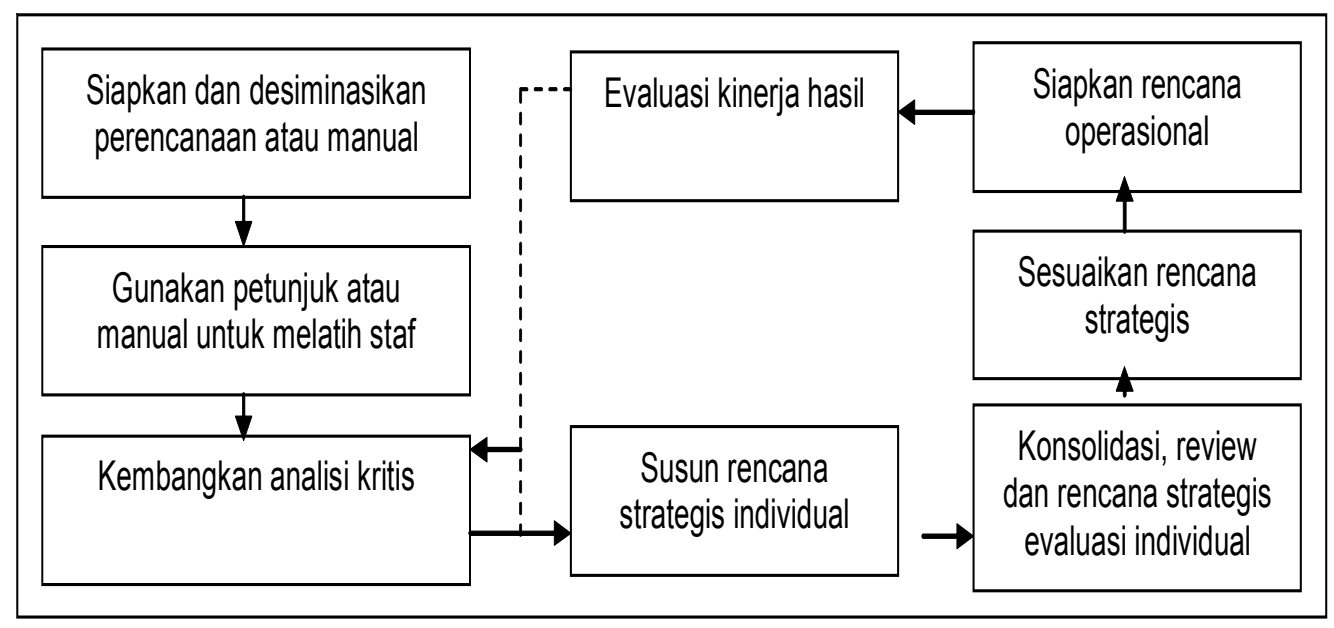

Gambar 2. Proses penyusunan rencana strategis diadaptasi dari Lewis (1983) dalam Sonhadji (2003) 
Merujuk pada gambar 2 di atas, sebuah proses perencanaan strategis meliputi beberapa tahap (stage). Tahap I prepare and desseminate planning guidelines or manual merupakan tahap penyiapan dan desiminasi panduan perencanaan atau manual. Pada tahap ini mencakup: (1) analisis kritis baik internal maupun eksternal, (2) kinerja yang lalu, (3) asumsi perencanaan, (4) tujuan jangka panjang, (5) strategi program, (6) anggaran jangka panjang, dan (7) rencana operasional. Tahap II use the planning guidelines or manual to train staf, pada tahap ini menggunakan semua petunjuk yang ada untuk kegiatan pelatihan staf sehingga kemampuan SDM meningkat. Tahap III ialah develop the critical analysis, yakni informasi yang diperlukan dalam kegiatan ini meliputi profil sekolah, profil siswa, dan profil wilayah. Tahap IV, construct individual strategic plans, memanfaatkan informasi dari semua aspek untuk mengembangkan rencana strategis. Tahap V consolidate, review, and evaluate individual strategic plans, hal yang harus dilakukan pada tahap ini meliputi: (1) melacak alokasi atau ketersediaan anggaran, (2) memberikan rekomendasi terhadap rencana yang mendapat sorotan, dan (3) menyusun bagaimana cara meningkatkan rencana.

Merujuk dari pemahaman tentang bagaimana proses perencanaan strategis terjadi maka implikasinya bagi SKB adalah (1) menerapkan proses perumusan rencana strategis secara ilmiah sehingga dapat dipertanggungjawabkan secara akademik, (2) mendiskusikan kembali dengan staf tentang rumusan rencana strategis yang telah disusun, melalui analisis SWOT yang memadai, dan ini yang justru jarang dilakukan oleh SKB. Hasilnya rencana strategis yang ada cenderung tidak mampu membaca apa yang sejatinya dirasakan dan dibutuhkan oleh pelanggan, dan (3) memaknai proses perumusan rencana strategis sebagai langkah yang diyakini dapat memberikan harapan kepada SKB yang efektif, SKB yang dapat memuaskan kebutuhan pelanggan akan layanan program-program PNF yang bermutu di SKB.

Kemudian pada tahap implementasi perencanaan strategis di lapangan, pelaksanaannya sangat tergantung pada komitmen dan konsistensi anggota organisasi yang ada di SKB; kepala SKB, pamong belajar, dan staf TU. Komitmen disini menyangkut dengan tanggung jawab dari setiap orang di dalam SKB untuk melaksanakan pekerjaannya dengan profesional. Adapun konsistensi merujuk pada ketaatan dan kepatuhan terhadap hal yang tertuang dalam rumusan perencanaan strategis melaksanakan keputusan dengan taat asas. Hal yang sering terjadi di SKB dalam mengimplementasikan perencanaan strategis adalah rendahnya komitmen dan konsistensi pada anggota organisasi yang ada di SKB, di antaranya (a) kurangnya komunikasi antara kepala SKB dengan pamong belajar, (b) pelaksanaan program yang kurang terkoordinasi dan terorganisir dengan baik sehingga masing-masing pihak jalan dengan konsepnya masingmasing, dan (c) pelaksanaan kegiatan yang jauh dari prinsip-prinsip profesional. Selanjutnya implementasi perencanaan strategis di lapangan tergantung pada kemampuan dan kepemimpinan kepala SKB dalam menggerakkan dan mengarahkan segala potensi sumber daya yang ada di SKB sehingga mencapai tujuan yang telah dirumuskan dalam rencana strategis.

Peran Perencanaan Strategis
dalam Pem-bangunan SKB
yang Efektif
SKB adalah Unit
Pelaksana Teknis Dinas (UPTD)
pendidikan nasional yang membidangi dan menangani permasalahan PNF. Undang-Undang (UU) No. 20 tahun 2003 Tentang Sistem Pendidikan Nasional menyebutkan bahwa terdapat tiga jalur pendidikan dalam rangka melayani kebutuhan warga masyarakat dibidang pendidikan, yaitu (1) pendidikan formal, (2) PNF, dan (3) pendidikan informal, di mana kedudukan, peran, dan fungsinya bersifat saling melengkapi dan menyempurnakan satu sama lain. PNF dalam sistem pendidikan nasional berfungsi sebagai pelengkap, penambah dan pengganti, serta output pendidikan juga mempunyai kompetensi yang setara sehingga mempunyai daya asesibilitas yang sama pula dengan pendidikan formal pada khususnya.

Seiring dengan otonomi daerah (otda), perubahan yang lebih besar banyak terjadi terutama menyangkut struktur, kedudukan, tugas, dan peranannya. Secara prinsip tugas dan fungsi SKB adalah sebagai berikut. (1) Menyelenggarakan kegiatan pembelajaran pendidikan kesetaraan, kursus, life skill, diklat, dan pendidikan anak usia dini. (2) Menyelenggarakan kegiatan pembinaan, pemantauan, dan evaluasi pembelajaran terhadap kelompok-kelompok belajar PNF. (3) Menyelenggarakan kegiatan administrasi sanggar. Meskipun dalam kenyataan di lapangan, kebijakan otda juga berdampak kurang menguntungkan bagi SKB, di antaranya banyak SKB yang dilikuidasi 
atau dimerger dengan instansi lain yang memiliki kesamaan tupoksi. Tetapi banyak juga yang mendapatkan keuntungan dari Otda, misalnya di kabupaten Boyolali, justru Pemda setempat memekarkan SKB menjadi lima buah SKB. Diakui atau tidak, kebijakan Otda memang membawa dampak yang beragam kepada SKB.

Dinamika PNF yang terus berkembang seiring dengan perubahan teknologi dan informasi, telah mendorong meningkatnya: (1) kebutuhan belajar warga belajar, (2) tuntutan layanan program PLS yang bermutu, dan (3) diversifikasi program sesuai dengan perkembangan jaman. Grand planning SKB dalam bentuk perencanaan strategis akan menjembatani kesenjangan yang ada. Untuk itu, perencanaan strategis yang disusun oleh SKB harus mengover halhal antara lain: (1) perumusan tujuan; (2) perumusan misi dan visi; (3) penentuan sasaran mengacu pada skala prioritas; dan (4) analisis lingkungan, menggunakan analisis SWOT. Perencanaan strategis yang disusun harus berorientasi kepada programprogram yang relevan dengan kebutuhan warga belajar serta potensi lingkungan sekitar.

Bertolak dari tugas dan fungsi pokok SKB maka kegiatan penyusunan rencana strategis merupakan kegiatan yang sangat penting. Bagaimana SKB mampu mencapai tujuan kelembagaannya dan strategi apa yang dapat dilakukan. Dalam tataran ini, penyusunan rencana strategis sebagai alat untuk mencapai tujuan sehingga SKB dapat disebut efektif maka langkah yang dilakukan oleh manajer puncak (kepala SKB) meliputi sebagai berikut.

1. Membentuk tim kerja.

2. Mengumpulkan dan mempelajari kebijakan; kebijakan global, semi, dan teknis.

3. Menentukan dan melakukan analisis SWOT.

4. Mengumpulkan data baik internal maupun eksternal.

5. Menentukan visi diawali dengan menginventarisir rumusan tugas satuan organisasi.
6. Menentukan misi yang juga diawali dengan menginventarisir rumusan tugas satuan organisasi.

7. Dalam satu misi maka tentukan beberapa tujuan.

8. Dalam satu tujuan tentukan sasaran prioritas.

9. Buatlah indikator sasaran keberhasilan (output dan outcome).

10. Tentukan cara mencapai tujuan dan sasaran yang dijabarkan dalam bentuk kebijakan program dengan memilih program yang tepat dan prioritas sesuai dengan tugas dan fungsi organisasi.

Mengamati peran perencanaan strategis sebagai kerangka membangun SKB yang efektif, penulis berpendapat bahwa peran tersebut meliputi: (1) membentuk kerangka perencanaan kerja yang kokoh yang dapat digunakan sebagai pijakan dalam menjalankan tupoksi SKB; (2) mendorong kinerja SKB ke arah yang lebih baik; (3) membangun perspektif yang positif terhadap keberadaan SKB ditengah masyarakat; (4) membantu SKB mengidentifikasi kelemahan, kekuatan, tantangan, dan peluang; (5) membantu mengoptimalkan sumber daya yang ada di SKB; dan (6) memberikan grand planning yang jelas dan terarah kepada SKB.

Selanjutnya, bertolak dari konsepsi di atas maka perencanaan strategis berfungsi sebagai alat (tool) efektif yang dapat digunakan sebagai (1) arahan atau bimbingan kepada SKB dalam mencapai tujuan; (2) membantu SKB memfokuskan kegiatan pada programprogram jangka pendek, menengah, dan panjang; (3) mengembangkan kerangka kerja yang efektif; dan (4) memberikan kajian dan identifikasi terhadap faktor keberhasilan dan hambatan.

Jadi, dengan adanya perencanaan strategis yang memadai maka akan muncul (1) sistem kerja yang baik sehingga mampu mensinergikan semua personel yang ada dalam SKB; (2) menghindari perilaku negatif, seperti bekerja tanpa target dan bekerja tidak profesional; serta (3) meningkatnya profesionalisme personel SKB.

\section{KESIMPULAN}

Organisasi merupakan kumpulan orang yang mempunyai kesamaan visi, misi, dan tujuan. Membangun organisasi yang efektif memerlukan komitmen dan persepsi yang sama pada setiap anggota organisasi. Pada organsiasi pendidikan seperti SKB, konsepsi keefektifan mengacu pada kinerja dan performa SKB dalam melaksanakan dan memberikan layanan program PNF kepada pelanggan, yaitu warga belajar dan masyarakat yang membutuhkan program-program
PNF. Secara sederhana efektivitas organisasi dapat dilihat dari tiga variabel, yaitu (1) masukan (inputs), (2) proses, dan (3) keluaran (outputs).

Upaya membangun organisasi SKB yang efektif dapat dilakukan melalui: (1) menyusun struktur organisasi yang kuat; (2) menyusun dan menetapkan target pencapaian tujuan; (3) memberikan sistem hadiah dan sanksi (reward and pusnishment) yang adil; (4) melakukan evaluasi kinerja individu; (5) 
menindaklanjuti hasil evaluasi; (6) melakukan proses analisis terkait dengan masukan-proses-keluaran melalui penetapan prosedur dan standar kualitas minimal yang ketat; (7) menyusun grand planning sebagai acuan atau pijakan perjalanan SKB; dan (8) membangun kerja sama, komunikasi, dan koordinasi dengan semua tingkatan manajer di dalam SKB.

Perencanaan strategis merupakan serangkaian tindakan atau keputusan yang dibuat berdasarkan analisis yang mendalam, salah satunya adalah analisis SWOT. Perencanaan strategis yang memadai harus mengandung (1) rumusan misi dan visi; (2) rumusan tujuan khusus yang jelas dan terbaca (visible and attainable); (3) berisi program aksi jangka panjang, menengah, dan pendek (long, middle and short terms); (4) menyertakan umpan balik yang tepat; (5) dilakukan melalui analisis lingkungan seperti SWOT; dan (6) memberikan daya prediksi yang tinggi sekaligus mem- berikan alternatif tindakan yang beragam.

Rencana strategis merupakan arah, petunjuk, dan acuan organisasi dalam mencapai tujuan (objectives). Efektif atau tidaknya SKB nampak dari perumusan tujuan sebagaimana tercantum dalam perencanaan strategis SKB. Peran rencana strategis dalam pembangunan SKB yang efektif meliputi: (1) memberikan arahan atau petunjuk dalam mencapai tujuan yang telah ditetapkan, (2) memberikan prediksi keberhasilan dan kegagalan terhadap pelaksanaan layanan program PNF di SKB, (3) meningkatkan kinerja dan performa SKB, (4) memberikan dorongan dan spirit yang kuat kepada orang-orang di SKB dalam meningkatkan kualitas layanan program PNF kepada pelanggan sehingga muncul kepuasan pada diri pelanggan, dan (5) memberikan harapan yang besar kepada orang-orang di SKB, harapan akan masa depan SKB yang lebih baik.

\section{DAFTAR PUSTAKA}

Ansoff, I., \& McDonnell, E. (1990). Implementing strategic management. $2^{\text {nd }}$ ed. London: Prentice-Hall.

Campbell, R.F., Corbally, J.E., \& Nystrand, R.O. (1983). Introduction to educational administration. Boston: Allyn and Bacon.

Gibson, J.L. (1989). Organization and management. (Alih bahasa Joerban Wahid). Jakarta: Erlangga.

Hasibuan, M.S.P. (1996). Organisasi dan motivasi: Dasar peningkatan produktivitas. Jakarta: Bumi Aksara.

Hersey, P., \& Blancard., K.H. (1977). Management of organizational behavior: Utilizing human resources. New Jersey: Prentice-Hall.

Ivanchevich, J.M. (1995). Human resource management: Foundation of personel. Illionis: Homewood.
Miskel, C.G,. \& Hoy. W.R. (2001). Educational administration: Theory, research and practice. Boston: McGraw-Hill.

Purnama, N. (2000). Membangun Keunggulan Bersaing melalui Integrasi Perencanaan Strategis dan Perencanaan SDM. Jurnal IImiah Usahawan No.07. Th. XXIX Juli 2000.

Sa'ud, U.S., \& Makmun, A.S. (2005). Perencanaan pendidikan: Suatu pendekatan komprehensif. Bandung: Rosda.

Sonhadji, A.K.H. (2003). Bahan-Bahan kuliah manajemen strategis. Modul Belajar tidak diterbitkan. Malang: Universitas Negeri Malang.

Schuller, R.S. (1990). Repositioning of Human Resources Function: Transformation or Demise. The Accademy of Management Executive. Vol. 4 No. 3 P. 49-59. 